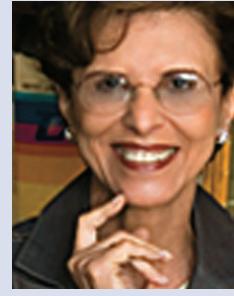

Sylvia Vergara

FGV-EBAPE

sylvia.vergara@fgv.br

\title{
Ordem e transgressão
}

\author{
JÁ FAZ CERCA DE CEM ANOS QUE FREDERICK TAYLOR E HENRI FAYOL FUNDARAM A \\ CHAMADA “ADMINISTRAÇÃO CIENTÍFICA", BASEADA NA ORDEM
}

Eles prescreveram normas, funções, tempos e movimentos que deveriam ser feitos pelo trabalhador na sua tarefa. A pergunta que muita gente faz é se os princípios desse tipo de administração ainda estão vivos. E nossa resposta é: felizmente, sim!

Ainda hoje os gestores definem estratégias, prescrevem atividades produtivas, controlam seus executantes, planos, carreiras, projetos, processos, modos de agir que tornam possível a incorporação de novas tecnologias, as relações entre os diversos grupos de relacionamento, a nutrição da cultura organizacional. Mas é claro que a ordem também pode ser transgredida.

De fato, os gestores percebem que as regras formais são transgredidas pelo corpo da organização, seja ele composto pela geração y, x ou dos baby-boomers. Prova disso é a criação das regras informais, que mitigam os equívocos e as inadequações das regras formais, propiciam negociações informais para o alcance de determinado objetivo, revelam-se como instrumentos de conciliação de interpretações opostas acerca de algo e desnudam novas aspirações e modos de encarar a hierarquia organizacional.

Um olhar sobre as organizações permite perceber que a transgressão de uma regra formal, dependendo de quem vem, pode gerar punições ou, ao contrário, promover um "fechar de olhos" do ges- tor, quando há evidências de melhora no funcionamento de processos organizacionais. Além disso, quanto mais nos situamos no topo da hierarquia de uma organização, mais estamos "autorizados" a transgredir regras. Afinal, de um executivo esperase inovação, criatividade, um "sair da caixa", ações que são, certamente, transgressões.

A ordem traz inúmeras possibilidades para o desenvolvimento organizacional. Mas possui seus limites. Ordem significa repetição, invariância, relação altamente provável, dependência de regras, redução de incerteza, mecanicismo. Se alguma organização fosse pura ordem, haveria o impedimento da inovação, da criação, da evolução. Em uma palavra: ela morreria.

A transgressão igualmente abre portas ao desenvolvimento da organização. Mas também tem seus limites. Transgressão está atrelada à desordem, à irregularidade, à imprevisibilidade, à incerteza, ao desvio. Se alguma organização fosse pura transgressão, perderia a estabilidade necessária à sua existência. Quer dizer, ela também morreria.

Que nos desculpem Taylor e Fayol, mas tendências recentes em gestão apontam para uma nova compreensão do valor da ordem e da transgressão. Elas admitem a co-existência de ambas como pólos contrários que se complementam e que dão vida às organizações. $\boldsymbol{x}$ 